\title{
CALIBRATION OF CARDY-ION METERS TO MEASURE NUTRIENT CONCENTRATIONS IN SOIL SOLUTION AND IN PLANT SAP
}

\author{
Marcos Vinícius Folegatti ${ }^{1 *}$; Flávio Favaro Blanco²; Rodrigo Marcelli Boaretto33; Antônio Enedi \\ Boaretto $^{3}$ \\ ${ }^{1}$ USP/ESALQ - Depto. de Engenharia Rural, C.P. 9 - 13418-900 - Piracicaba, SP - Brasil. \\ ${ }_{3}^{2} U S P / E S A L Q$ - Programa de Pós-Graduação em Irrigação e Drenagem. \\ ${ }^{3}$ USP/CENA - Lab. de Nutrição Mineral de Plantas, C.P. 96 - 13400-970 - Piracicaba, SP - Brasil. \\ *Corresponding author <mvfolega@esalq.usp.br>
}

\begin{abstract}
Fertigation management requires rapid and accurate methods to determine nutrient concentrations in soil solution and in plant sap. This study was developed to evaluate the performance of cardy-ion meters (CIM) for the determinations of $\mathrm{NO}_{3}^{-}, \mathrm{K}^{+}$and $\mathrm{Na}^{+}$concentrations in soil solution and tomato plant sap, for fertigation management purposes. Tomato was cultivated in a greenhouse with different levels of $\mathrm{N}, \mathrm{K}$ and $\mathrm{Na}$ in the irrigation water. Soil solution was collected by suction at the $15 \mathrm{~cm}$ depth with porous ceramic cups and the concentrations of $\mathrm{NO}_{3}^{-}, \mathrm{K}^{+}$and $\mathrm{Na}^{+}$were determined by CIM and also in the laboratory by standard methods. At the end of the cropping season, 50 leaf samples were also collected and concentrations of the nutrients in the petiole sap were analyzed by CIM and compared to the amounts of total-N, K and Na in the dry matter of the leaves. Concentrations in soil solution and plant sap determined by CIM presented good correlations with measurements in soil solution and in leaf dry matter, respectively, analysed by standard methods. The use of CIM is advantageous due to the quickness of the analyses and the low cost.

Key words: ion electrodes, fertigation, mineral nutrition, soil solution extractor, tomato
\end{abstract}

\section{CALIBRAÇÃO DE MEDIDORES DE ÍONS ESPECÍFICOS PARA DETERMINAÇÃO DA CONCENTRAÇÃO DE NUTRIENTES NA SOLUÇÃO DO SOLO E NA SEIVA DA PLANTA}

\begin{abstract}
RESUMO: O manejo da fertirrigação requer métodos rápidos e precisos para a determinação das concentrações de nutrientes na solução do solo e na seiva da planta. Este estudo foi desenvolvido para avaliar o desempenho de medidores de íons específicos (MIE) na determinação das concentrações de $\mathrm{NO}_{3}^{-}, \mathrm{K}^{+}$and $\mathrm{Na}^{+}$na solução do solo e na seiva de plantas de tomate para fins de manejo da fertirrigação. $O$ tomateiro foi cultivado em um ambiente protegido com diferentes níveis de N, K e Na na água de irrigação. A solução do solo foi coletada a $15 \mathrm{~cm}$ de profundidade com cápsulas de cerâmica porosa e as concentrações de $\mathrm{NO}_{3}^{-}, \mathrm{K}^{+}$and $\mathrm{Na}^{+}$foram determinadas com os MIE e também no laboratório pelos métodos-padrões. Ao final do ciclo da cultura, 50 amostras de folhas também foram coletadas e as concentrações dos nutrientes na seiva do pecíolo foram analisadas com os MIE e comparadas com os teores de N, K e Na na matéria seca das folhas. As concentrações na solução do solo e na seiva da planta determinadas com os MIE apresentaram boas correlações com as determinações na solução do solo e na matéria seca das folhas, respectivamente, efetuadas pelos métodospadrões. A utilização dos MIE é vantajosa devido à rapidez das análises e aos baixos custos.

Palavras-chave: eletrodos, fertirrigação, nutrição mineral, extrator da solução do solo, tomate
\end{abstract}

\section{INTRODUCTION}

Plants require an adequate supply of nutrients throughout their growing season for optimal growth, so the concentration of nutrients in soil solution should be maintained at a satisfactory level (Mengel \& Kirkby, 1987). Monitoring nutrient levels in soil and plant tissues is often usual to define nutrient requirements of the crop. However, to be effective, the analyses must be completed within two or three days after plant sampling, or else an observed deviation from the optimum may adversely affect growth and reduce yields (Bar-Yousef, 1991).
For plants cultivated in solutions containing $\mathrm{NO}_{3}^{-}$, plant sap $\mathrm{NO}_{3}^{-}$concentration is a highly sensitive indicator of their nutritional status (Scaife \& Stevens, 1983). Guimarães et al. (1998) and Smith et al. (2000) proved the functionality and accuracy of the portable Horiba ${ }^{\circledR}$ cardy-ion meter (CIM) for determination of $\mathrm{NO}_{3}{ }^{-}$concentration in tomato and cotton sap, respectively. These authors compared sap concentrations determined by CIM with those of leaf dry matter and obtained coefficients of determination $\left(r^{2}\right)$ greater than 0.90 .

The CIM are provided with a specific ion electrode, allowing rapid determinations in the field of soil 
solution and plant sap ion concentrations. Carlson \& Keeney (1971) report some advantages and disadvantages in the use of specific ion electrodes. The main advantage is the short time required for analysis if the electrode can be used directly without sample preparation, as with the analyses of soil solution and plant sap, which are directly measured by dripping a sample on the electrode. The main disadvantage of electrodes is the interference of other ions; practically none of the electrodes are completely specific.

Kallenbach (2000) showed that the accuracy of CIM for $\mathrm{K}^{+}$concentration measurements in solution was affected by the source of $\mathrm{K}^{+}$used $\left(\mathrm{KCl}, \mathrm{KNO}_{3}\right.$ or $\left.\mathrm{K}_{2} \mathrm{SO}_{4}\right)$. Thus, the calibration constant of the CIM may vary accordingly to the fertilizer used and presence of interfering ions, which turns the calibration specific for each condition.

This study was therefore developed to evaluate the performance of CIM on the determination of $\mathrm{NO}_{3}$, $\mathrm{K}^{+}$and $\mathrm{Na}^{+}$concentrations in soil solution and tomato plant sap. Although $\mathrm{Na}^{+}$is not an important ion for tomato, its concentration in soil solution and in plant sap is a valuable information for management decisions when using saline irrigation water.

\section{MATERIAL AND METHODS}

A greenhouse pot experiment was carried out in Piracicaba, SP, Brazil (latitude 22 $44^{\circ}$ S, longitude $47^{\circ} 39^{\prime}$ $\mathrm{W}$ and altitude $580 \mathrm{~m}$ ). Soil solution samples were collected during an experiment designed to study the response of tomato to different levels of $\mathrm{N}, \mathrm{K}$ and salinity of the irrigation water, in a $3 \times 3 \times 3$ factorial scheme, with five replications, totaling 135 pots. Fertilizers and salts used were $\mathrm{NH}_{4} \mathrm{NO}_{3}, \mathrm{KCl}, \mathrm{CaCl}_{2}$ and $\mathrm{NaCl}$, which were applied by drip fertigation. Tomato seedlings, hybrid Facundo, were transplanted on October 23, 2001, to a greenhouse covered with polyethylene film of $0.15 \mathrm{~mm}$ thickness, with anti-aphid screen at the laterals. Seedlings

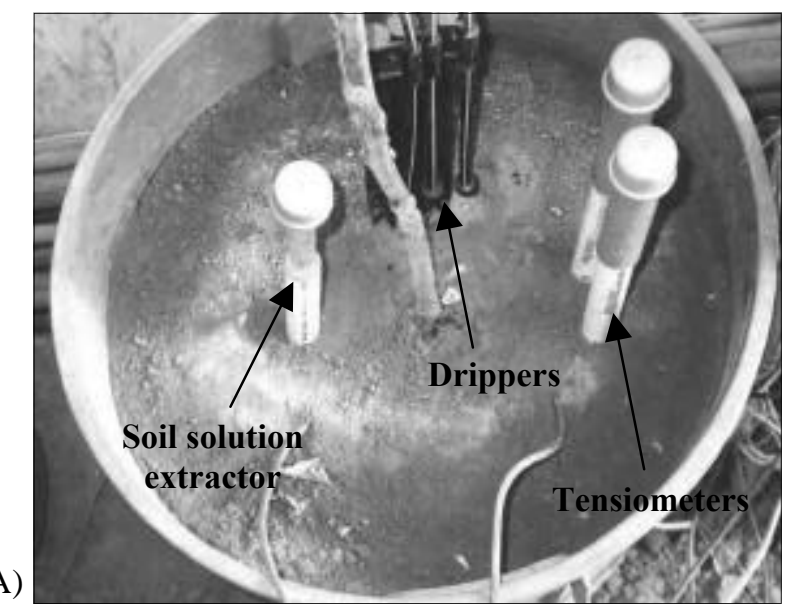

where transplanted to pots containing about $60 \mathrm{~kg}$ of airdried sandy-clay loam soil and with a gravel base layer covered with a polypropylene screen in the bottom to allow drainage when excess water was applied. After the pot was filled with the soil, it was tamped to obtain a bulk density of $1300 \mathrm{~kg} \mathrm{~m}^{-3}$ and a soil depth of $0.35 \mathrm{~m}$.

Soil solution was collected every 15 days, on average, with porous ceramic cups (Figure 1) installed at the $0.15 \mathrm{~m}$ depth in all pots, starting after the first irrigation with saline water, 27 days after transplanting. A vacuum of $-70 \mathrm{kPa}$ was applied for $24 \mathrm{~h}$ beginning $24 \mathrm{~h}$ after irrigations. The collected soil solution was removed from the cup and stored at $4^{\circ} \mathrm{C}$. Six samplings were accomplished and, at the end of the experimental period (127 days after transplanting), some samples were chosen in order to represent the range of concentrations observed during the crop season analysed by CIM and in laboratory by standard methods.

Analyses of soil solution were performed on 350 samples for $\mathrm{K}^{+}$and $\mathrm{Na}^{+}$and 82 samples for $\mathrm{NO}_{3}^{-}$, because the procedure for $\mathrm{NO}_{3}^{-}$is highly laborious and time consuming. Ion concentrations determined by CIM were compared with those determined in the laboratory by standard methods: flame photometry for $\mathrm{K}^{+}$and $\mathrm{Na}^{+}$(Rich, $1965)$ and steam-distillation for $\mathrm{NO}_{3}^{-}$(Bremner, 1965).

Fifty samples of young fully expanded leaves corresponding to the different treatments were collected and the concentrations of $\mathrm{NO}_{3}^{-}, \mathrm{K}^{+}$and $\mathrm{Na}^{+}$were determined by CIM in the petiole sap. Only the base of the petiole was used (Figure 1B) and sap was squeezed using a handheld garlic press. After removing the base of the petioles, leaves were oven-dried at $60^{\circ} \mathrm{C}$ for $48 \mathrm{~h}$ and the amounts of total-N, $\mathrm{K}$ and $\mathrm{Na}$ in the dry matter were also determined in laboratory by the methodology proposed by Malavolta et al. (1997).

To ensure precise readings, the CIM were washed with distilled water between samples and a two-point calibration was performed with a standard solution after 10

Figure 1 - Experimental pot showing the relative position of the soil solution extractor (A); scheme of a tomato leaf showing the part of the petiole used for sap determinations (B). 
readings. Concentrations of $\mathrm{NO}_{3}^{-}, \mathrm{K}^{+}$and $\mathrm{Na}^{+}$determined by CIM in soil solution and petiole sap were compared with the corresponding values measured in the laboratory, except for $\mathrm{NO}_{3}{ }^{-}$in sap, which was compared with total$\mathrm{N}$ in leaf dry matter. The relationship between the CIM and the standard methods for each ion was tested by the paired-t test (Steel \& Torrie, 1980). Structural analysis (Menk \& Igue, 1992) was performed and linear equations were fitted to data to verify correlations and coefficients of determination, $\mathrm{r}^{2}$.

\section{RESULTS AND DISCUSSION}

Strong correlations were observed for concentrations of $\mathrm{NO}_{3}^{-}, \mathrm{K}^{+}$and $\mathrm{Na}^{+}$determined by CIM and by standard methods (Figure 2). Concentrations of $\mathrm{NO}_{3}^{-}$measured by CIM were about 39\% lower than those determined by the distillation method, while for $\mathrm{K}^{+}$and $\mathrm{Na}^{+}$ the values obtained with CIM were $21 \%$ and $67 \%$ greater, respectively, than the concentrations determined by flame photometry.

Coefficients of determination $\left(\mathrm{r}^{2}\right)$ were high for all ions, and the relationships were significant at $1 \%$ (Table 1), indicating high precision of the estimations. Thus, the CIM is suitable to assess the ionic concentration in soil solution, providing rapid and accurate measurements for fertigation management.
Concentrations of $\mathrm{NO}_{3}^{-}, \mathrm{K}^{+}$and $\mathrm{Na}^{+}$in petiole sap determined by CIM were reasonably well correlated with those determined in leaf dry matter (Figure 3), and relationships were significant for all ions (Table 1).

The values of $r^{2}$ for the concentrations in the petiole sap and in leaf dry matter were close to those observed by other authors. Ronchi et al. (2001) found $r^{2}$ of 0.65 when the $\mathrm{N}^{-\mathrm{NO}_{3}}{ }_{3}^{-}$determined in petiole sap was compared to total-N in leaf dry matter. Locascio et al. (1997) cultivated tomato in different locations and verified that the $r^{2}$ varied from zero to 0.80 , depending on the location and crop age, while Guimarães et al. (1998) found $r^{2}$ from 0.37 to 0.97 depending on the sampled leaf and soil type. Comparisons of $\mathrm{Na}^{+}$measured in petiole sap and dry matter were not found in the available literature.

Table 1 - Values of paired-t test for concentrations of $\mathrm{NO}_{3}^{-}$, $\mathrm{K}^{+}$and $\mathrm{Na}^{+}$determined by CIM and by standard methods, in the soil solution and tomato petiole sap.

\begin{tabular}{llll}
\hline Statistic & $\mathrm{NO}_{3}{ }^{-}$ & \multicolumn{1}{c}{$\mathrm{K}^{+}$} & $\mathrm{Na}^{+}$ \\
\hline \multirow{3}{*}{$\mathrm{t}$} & \multicolumn{3}{c}{ Soil solution } \\
\cline { 2 - 4 } & $-12.1^{* *}$ & $12.3^{* *}$ & $26.4^{* *}$ \\
$\mathrm{t}$ & \multicolumn{3}{c}{ Petiole sap } \\
\cline { 2 - 4 } & $13.4^{* * \xi}$ & $13.9 * *$ & $14.0 * *$ \\
\hline
\end{tabular}

**Significant at 0.01 .

${ }^{\xi} \mathrm{NO}_{3}^{-}$in sap tested against total-N in leaf dry matter.
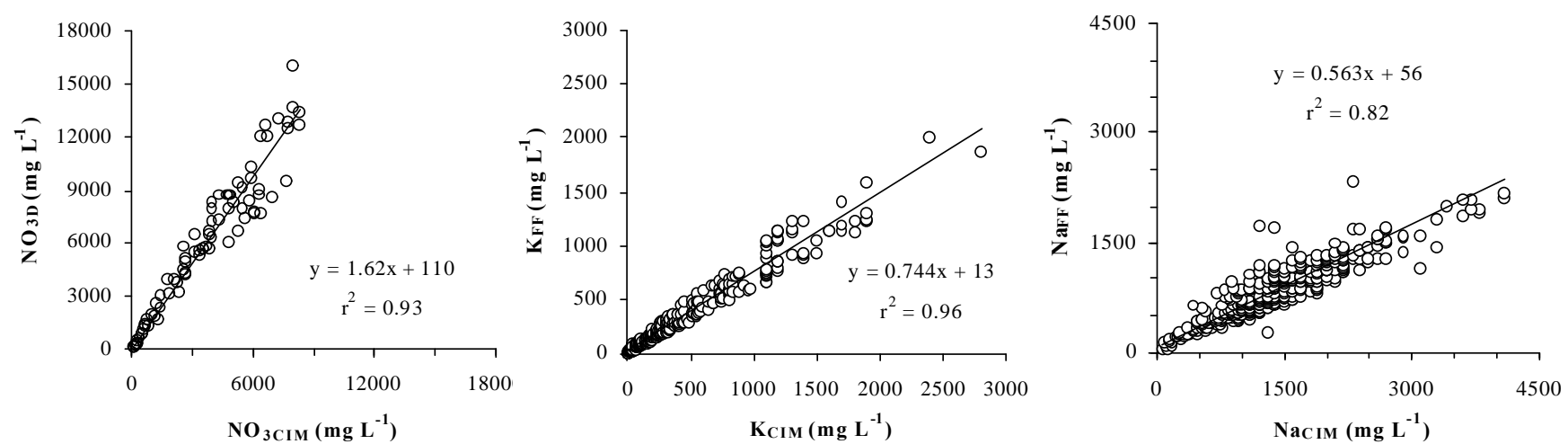

Figure 2 - Relationships between concentrations of nitrate, potassium and sodium in the soil solution measured by cardy-ion meters (CIM) and by standard methods. FF = flame fotometry; $\mathrm{D}=$ steam-distillation.
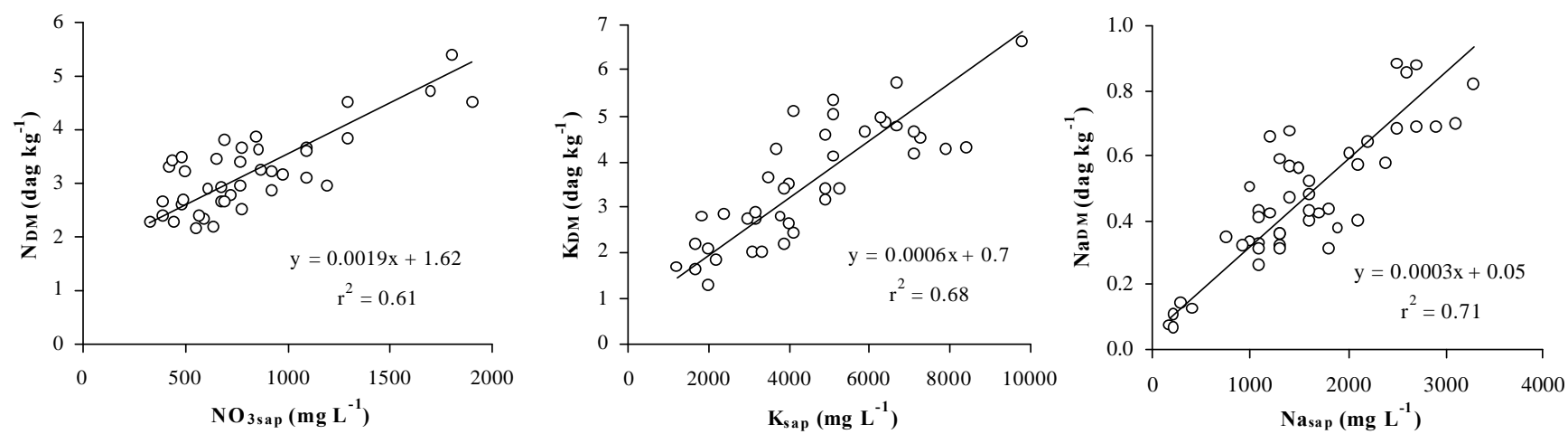

Figure 3 - Relationships between the concentrations of nitrate, potassium and sodium in petiole sap and total-N, potassium and sodium in the dry matter (DM) of tomato leaves, hybrid Facundo. 
Discrepancies observed between the CIM and standard method measurements are probably due to the influence of other ions present in solution and sap. Kallenbach (2000) found that values of $r^{2}$ between concentration of $\mathrm{K}^{+}$in sap and in dry matter of alfalfa leaf was always bellow 0.60 and better correlations were obtained when other variables were taken into account (i.e., leaf moisture, length of the longest stem). Guimarães et al. (1998) found a wide range of $r^{2}$ values (0.37 to 0.97) when $\mathrm{NO}_{3}^{-}$in petiole sap was compared to total- $\mathrm{N}$ in leaves of tomato; better results were obtained for leaves located near the first cluster and for sandy soils than for leaves near the third cluster and for clayey soil.

In this study, CIM was found to be a useful tool to assess ion concentrations in the soil solution and leaves. An economical analysis was performed in order to verify the viability of the CIM. The cost of CIM for $\mathrm{NO}_{3}{ }_{3}^{-}$is US $\$ 339$, and for $\mathrm{K}^{+}$and $\mathrm{Na}^{+}$, US $\$ 329$ each, while additional sensors cost US\$79 and, according to the manufacturer, each sensor can accomplish 200 to 400 measurements. Considering the taxes to import the equipment and supposing that, during their life expectancy, 2,000 samples could be analyzed, the total cost of these analyses would be US\$1,220 for $\mathrm{NO}_{3}^{-}$and US $\$ 1,205$ each for $\mathrm{K}$ and $\mathrm{Na}$. If the same analyses would be made in the laboratory, considering US $\$ 4$ the average value for $\mathrm{NO}_{3}{ }^{-}$ and US $\$ 1$ for $\mathrm{K}^{+}$and $\mathrm{Na}^{+}$, the total costs would increase to US $\$ 8,000$ for $\mathrm{NO}_{3}^{-}$and US $\$ 2,000$ for $\mathrm{K}^{+}$and $\mathrm{Na}^{+}$. Using the same reasoning and considering the costs of the determinations in leaf dry matter as US\$6 per sample, that includes the determination of $\mathrm{N}, \mathrm{K}$ and $\mathrm{Na}$ amounts, the total cost would be US $\$ 12,000$, while by CIM only US $\$ 2,425$ would be spent.

Besides the good and reasonable accuracy of the CIM in determining the ionic content in soil solution and in leaf sap, it allows a substantial money and time savings, once the analyses can be made immediately after the samples are obtained in the field. It is therefore concluded that the cardy-ion meters are suitable for determining ions in soil solution and petiole sap, giving good correlations with the values obtained by the standard methods, and allow a reduction in cost and time of the analyses.

\section{ACKNOWLEDGEMENT}

To, FAPESP, for financial support.

\section{REFERENCES}

BAR-YOUSEF, B. Fertilization under drip irrigation. In: PALGRAVE, D.A. (Ed.) Fluid fertilizer: science and technology. New York: Marcel Dekker, 1991. cap.14, p.285-329.

BREMNER, J.M. Inorganic forms of nitrogen. In: BLACK, C.A.; EVANS, D.D.; WHITE, J.L.; ENSMINGER, L.E.; CLARK, F.E. (Ed.) Methods of soil analysis: chemical and microbiological properties. part 2. Madison: ASA, 1965. cap.84, p.1179-1237. (Agronomy, 9).

CARLSON, R.M.; KEENEY, D.R. Specific ion electrodes: techniques and uses in soil, plant, and water analysis. In: WALSH, L.M. (Ed.) Instrumental methods for analysis of soils and plant tissue. Madison: SSSA, 1971. cap.3, p.39-65.

GUIMARÃES, T.G.; FONTES, P.C.R.; PEREIRA, P.R.G.; ALVAREZ V., V.H.; MONNERAT, P.H. Determinação dos teores de nitrogênio na seiva do tomateiro por meio de medidor portátil. Horticultura Brasileira v.16, p.144-151, 1998.

KALLENBACH, R.L. Field use of an ion-specific electrode to measure the potassium concentration in alfalfa. Crop Science, v.40, p.772-777, 2000.

LOCASCIO, S.J.; HOCHMUTH, G.J.; RHOADS, F.M.; OLSON, S.M.; SMAJSTRLA, A.G.; HANLON, E.A. Nitrogen and potassium application scheduling effects on drip-irrigated tomato yield and leaf tissue analysis. HortScience, v.32, p.230-235, 1997.

MALAVOLTA, E.; VITTI, G.C.; OLIVEIRA, S.A. Avaliação do estado nutricional das plantas: princípios e aplicações. 2.ed. Piracicaba: POTAFOS, 1997. 201p.

MENGEL, K.; KIRKBY, E.A. Principles of plant nutrition. 4.ed. Bern: International Potash Institute, 1987. 687p.

MENK, J.R.F.; IGUE, T. Relacionamento de dados de solos entre métodos analíticos: o caso da análise granulométrica. Revista Brasileira de Ciência do Solo, v.16, p.143-152, 1992.

RICH, C.I. Elemental analysis by flame photometry. In: BLACK, C.A.; EVANS, D.D.; WHITE, J.L.; ENSMINGER, L.E.; CLARK, F.E. (Ed.) Methods of soil analysis: chemical and microbiological properties. part 2. Madison: ASA, 1965. cap.54, p.849-865. (Agronomy, 9).

RONCHI, C.P.; FONTES, P.C.R.; PEREIRA, P.R.G.; NUNES, J.C.S.; MARTINEZ, H.E.P. Índices de nitrogênio e de crescimento do tomateiro em solo e em solução nutritiva. Revista Ceres, v.48, p.469-484, 2001.

SCAIFE, A.; STEVENS, K.L. Monitoring sap nitrate in vegetable crops: comparison of test strips with electrode methods, and effects of time of day and leaf position. Communications in Soil Science and Plant Analysis, v.14, p.761-771, 1983.

SMITH, J.H.; SILVERTOOTH, J.C.; NORTON, E.R. Comparison of the two methods for the analysis of petiole nitrate nitrogen concentration in irrigated cotton. http://ag.arizona.edu/pubs/crops/az1006/ az10068c.html. (08 Jan. 2000).

STEEL, R.G.D.; TORRIE, J.H. Principles and procedures of statistics: a biometrical approach. 2.ed. New York: McGraw-Hill, 1980. 633p.

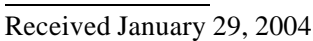

Accepted September 24, 2004 